\title{
Protein $N$-glycosylation in eukaryotic microalgae and its impact on the production of nuclear expressed biopharmaceuticals
}

\section{Elodie Mathieu-Rivet ${ }^{1+}$, Marie-Christine Kiefer-Meyer ${ }^{1+}$, Gaëtan Vanier ${ }^{1}$, Clément Ovide $^{1}$, Carole Burel ${ }^{1}$, Patrice Lerouge ${ }^{1}$ and Muriel Bardor ${ }^{1,2 *}$}

' Laboratoire Glyco-MEV, Faculté des Sciences et Techniques, UPRES EA 4358, Normandie Université, IRIB, VASI, Mont-Saint-Aignan, France

2 Institut Universitaire de France, Paris, France

\section{Edited by:}

Els J. M. Van Damme, Ghent

University, Belgium

Reviewed by:

Richard Strasser, University of

Natural Resources and Life

Sciences, Austria

Eva L. Decker, University of

Freiburg, Germany

*Correspondence:

Muriel Bardor, Laboratoire

Glyco-MEV (Glycobiologie et Matrice

Extracellulaire Végétale), UPRES EA

4358, UFR des Sciences et

Techniques, Normandie Université,

IRIB, VASI, Bâtiment Gadeau de

Kerville, 1 rue Tesnière, 76821 Mont

Saint Aignan Cedex, France

e-mail:muriel.bardor@univ-rouen.fr

${ }^{\dagger}$ The two first authors equally contributed to the work.
Microalgae are currently used for the production of food compounds. Recently, few microalgae species have been investigated as potential biofactories for the production of biopharmaceuticals. Indeed in this context, microalgae are cheap, classified as Generally Recognized As Safe (GRAS) organisms and can be grown easily. However, problems remain to be solved before any industrial production of microalgae-made biopharmaceuticals. Among them, post-translational modifications of the proteins need to be considered. Especially, $N$-glycosylation acquired by the secreted recombinant proteins is of major concern since most of the biopharmaceuticals are $\mathrm{N}$-glycosylated and it is well recognized that glycosylation represent one of their critical quality attribute. Therefore, the evaluation of microalgae as alternative cell factory for biopharmaceutical productions thus requires to investigate their $\mathrm{N}$-glycosylation capability in order to determine to what extend it differs from their human counterpart and to determine appropriate strategies for remodeling the microalgae glycosylation into human-compatible oligosaccharides. Here, we review the secreted recombinant proteins which have been successfully produced in microalgae. We also report on recent bioinformatics and biochemical data concerning the structure of glycans $N$-linked to proteins from various microalgae phyla and comment the consequences on the glycan engineering strategies that may be necessary to render those microalgae-made biopharmaceuticals compatible with human therapy.

Keywords: microalgae, biopharmaceuticals, glycosylation pathway, glycan, Chlamydomonas reinhardtii, Phaeodactylum tricornutum, endoplasmic reticulum, Golgi apparatus

\section{INTRODUCTION}

Nowadays, biopharmaceuticals on the market consists of 200 products yielding overall global revenue greater than US\$100 billion (Walsh, 2010). Over the past 5 years, 140 biopharmaceuticals were approved in the European Union (EU) and the United States (US) markets (Walsh, 2010). These biopharmaceuticals are produced in various systems ranging from bacteria to mammalian cell cultures (Wong, 2005; Demain and Vaishnav, 2009; Huang et al., 2012). Among those, the Chinese Hamster Ovary $(\mathrm{CHO})$ cells are currently the predominant industrial cell lines used for producing those drugs (Hossler et al., 2009), covering about $50 \%$ of the market (Demain and Vaishnav, 2009). However, the constant increasing needs for large amount of such therapeutic proteins, their high production cost in conventional expression systems and complicating factors related to potential virus contamination have driven scientists to explore new alternative production systems. In this context, various plant expression systems have emerged, including whole plants (Nicotiana, Alfalfa, Maize for examples) and in vitro culture systems such as plant cell suspensions (Nicotiana tabaccum, Lemna minor, Physcomitrella patens) and hairy roots
(Stoger et al., 2005; Drake et al., 2009; Colgan et al., 2010; Decker and Reski, 2012; Parsons et al., 2012; Xu et al., 2012; Schillberg et al., 2013; Twyman et al., 2013; Buyel and Fischer, 2014). Several plant-made biopharmaceuticals have been successfully produced (De Muynck et al., 2010). This includes the Cerezyme's biosimilar (glucocerebrosidase) which has been produced in carrot cells (Shaaltiel et al., 2007) and was approved on May 2012 by the US Food and Drug Administration (Maxmen, 2012). Despite those successes, there is an increasing interest to use microalgae for biopharmaceutical production. Microalgae are unicellular photosynthetic organisms which encompass between 40,000 and probably several billion species (Cadoret and Bernard, 2008; Mata et al., 2010). As plants, microalgae are classified in Generally Recognized As Safe (GRAS) organisms. Moreover, they are cheap and easy to grow, making them potentially attractive cell factories for the large-scale production of recombinant proteins.

To date, microalgae have been mainly used for the production of food compounds or high-value added compounds like carotenoids (Spolaore et al., 2006; Sasso et al., 2012). In addition, as photosynthetic organisms, microalgae are very 
efficient in converting sunlight into chemical energy, making them attractive for the production of carbohydrates, lipids, and hydrogen. Therefore, algal biomass represents a great potential for generating new sources of bioenergy such as biofuels (Beer et al., 2009; Lam and Lee, 2012; Merchant et al., 2012) and biomaterials (Hempel et al., 2011a). Several microalgae species have also been evaluated for their potential to express recombinant proteins. Among them, the model Chlorophyceae Chlamydomonas reinhardtii is currently the most investigated one for such a biotechnological application, due to the availability of genomic data and the existence of a powerful molecular toolkit including vectors allowing nuclear or chloroplastic transformation (Merchant et al., 2007; Harris, 2009). Additionally, the diatom Phaeodactylum tricornutum is also considered as an emerging system for such an application (Hempel et al., 2011b; Hempel and Maier, 2012) as it can be genetically modified and grown quite easily. Other species are also good candidates for large-scale production of recombinant proteins, especially due to their ease to obtain algal biomass and their growth rate. For example, a marine green microalga from the class of the Chlorophyceae, Dunaliella salina (Geng et al., 2003), but also species from the genus Chlorella [i.e., Chlorella vulgaris, recently renamed Coccomyxa sp. C-169 subellipsoidea (Blanc et al., 2010), Chlorella ellipsoidea], which belongs to the Trebouxiophyceae, are promising bio-factories for large-scale production of highvalue added proteins (Hawkins and Nakamura, 1999; Chen et al., 2001; Kim et al., 2002; Bai et al., 2013). However, molecular biology tools remain poorly developed for most of those microalgae even if genomic data became available (http://genome. jgi.doe.gov/; http://www.phytozome.net/; http://www.ncbi.nlm. nih.gov/genome).

Whatever the considered species, many problems have still to be solved before any industrial production and commercialization of microalgae-made biopharmaceuticals. Among them, increasing the yield and secretion of recombinant protein represents a crucial issue to make these organisms competitive with traditionally used expression systems such as the $\mathrm{CHO}$ cell lines. Furthermore, post-translational modifications need to be considered. Especially, $N$-glycosylation acquired by the secreted recombinant proteins is crucial for biopharmaceuticals since more than one third of the approved ones are glycosylated (Gomord et al., 2010) and it represents a critical quality attribute for them (Lingg et al., 2012). Indeed, the presence and structures of the $N$-glycans are required for their biological activity, stability and half-life (Lingg et al., 2012). The evaluation of microalgae as alternative cell factory for biopharmaceutical production thus requires investigating their $N$-glycosylation capability in order to determine to what extend their $N$-glycans differ from their human counterpart. In this paper, we report on bio-informatic and biochemical data concerning the structures of glycan $N$ linked to endogenous proteins from various microalgae phyla. Based on these recent findings, strategies for the engineering of the glycosylation pathways in these new expression systems are proposed to obtain microalgae-made biopharmaceuticals that would carry oligosaccharides compatibles with human therapies.

\section{MICROALGAE AS ALTERNATIVE SYSTEMS FOR PRODUCTION OF RECOMBINANT PROTEINS AVAILABLE TOOLS FOR NUCLEAR TRANSFORMATION IN MICROALGAE Chlamydomonas reinhardtii}

Currently, most of the studies reporting the expression of recombinant proteins in microalgae have been performed in the green alga Chlamydomonas reinhardtii. The majority of such productions has been targeted to the chloroplast. This concerned biopharmaceuticals such as the single-chain antibody directed against the glycoprotein D of the herpes simplex virus (Mayfield et al., 2003), but also the heavy and light chains of the antibody 83K7C, derived from a human IgG1 (Tran et al., 2009), human erythropoietin, domains 10 and 14 of human fibronectin, interferon $\beta 1$, proinsulin, vascular endothelial growth factor (VEGF), high mobility group protein B1(HMGB1) (Rasala et al., 2010) and two different immunotoxin proteins (Tran et al., 2012). Recently, an attenuated form of the E7 oncoprotein of the human papillomavirus (HPV) has also been produced in the same organelle (Demurtas et al., 2013). Indeed, this strategy is the most promising one to get high protein yields since $C$. reinhardtii possesses a large single chloroplast, representing about $40 \%$ of the total cell volume, and the proteins expressed in this organelle have been shown to represent $2-20 \%$ of total soluble proteins (Rasala and Mayfield, 2011). Moreover, three proteins have been shown to be expressed at levels which are sufficient for commercial production (Rasala et al., 2010). In contrast, secreted proteins produced from nuclear transformation in C. reinhardtii generally failed to accumulate to an equivalent level as the one observed in chloroplasts (Fuhrmann et al., 1999; Schroda et al., 2000; Specht et al., 2010). The low proteolysis in chloroplast could explain the high yields of recombinant proteins reached in this organelle (Surzycki et al., 2009; Potvin and Zhang, 2010). However, as far as glycosylated proteins such as biopharmaceuticals are concerned, chloroplast lacks the enzymatic machinery required for $\mathrm{N}$-glycosylation. Therefore, for biopharmaceutical production, both nuclear expression and protein transport through the secretory pathway of microalgae are required.

Despite recent progress, nuclear expression remains challenging in C. reinhardtii (Specht et al., 2010). Indeed, low levels of expression usually observed could result from transgene silencing (Cerutti et al., 1997; Shaver et al., 2010; Rasala et al., 2012). Its GC-rich genome (Merchant et al., 2007) has been also thought to be a hindrance to the expression of foreign genes since it introduces a codon usage bias. Several strategies have been developed during the last decade to circumvent these problems. Among them, the necessity to optimize the coding sequence of the gene of interest appears to be essential for improving the nuclear expression of the foreign protein (Fuhrmann et al., 1999). With regards to promoter sequences, a few assays have been performed to express reporter genes under the control of the plant constitutive CaMV35S promoter (Ruecker et al., 2008; Díaz-Santos et al., 2013) or of other viral sequences (Ruecker et al., 2008). Recently, a high light-inducible promoter from Dunaliella has also been investigated in C. reinhardtii. This promoter has been shown to drive efficiently the expression of the luciferase reporter gene but it has not been used for expression of any biopharmaceutical yet 
(Park et al., 2013). Currently, the major part of nuclear transgenes are expressed through a hybrid promoter, resulting from the fusion of the photosystem I complex (PSAD) (Fischer and Rochaix, 2001) or the Ribulose Bisphosphate Carboxylase Small Subunit (RBCS2) (Kindle, 1998) promoters with the HSP70A promoter which allows increasing the expression of the transgene (Schroda et al., 2000). In addition, several regulatory sequences have been included in the transgene coding sequence to enhance its expression. Thus, the insertion of the first intron of RBCS2 (Lumbreras et al., 1998), but also of the second and third introns (Eichler-Stahlberg et al., 2009) are required to increase the efficacy of the HSP70A/RBCS2 promoter. Compared to the CaMV35S promoter, these chimeric promoters remain actually the most efficient to drive the constitutive expression of nuclear transgenes in C. reinhardtii (Ruecker et al., 2008; Eichler-Stahlberg et al., 2009; Neupert et al., 2009; Rasala et al., 2012; Kumar et al., 2013). However, with a yield of secreted EPO estimated to $0.1 \mathrm{mg}$ per liter of culture medium (Eichler-Stahlberg et al., 2009), the expression level of EPO under the control of the HSP70A/RBCS2A promoter remains too low for large scale production.

Rasala et al. (2012) developed a new vector in which the gene of interest is fused to the $B L E$ gene of selection (which confers the resistance to bleomycin) via the nucleotide sequence encoding the foot-and-mouth-disease-virus 2A self-cleavage peptide (FMDV 2A) under the control of the HSP70A/RBCS2 promoter. The resulting translated product is processed into two proteins, with the $2 \mathrm{~A}$ peptide fused to the C-terminal end of the first protein as already described for other expressions using a 2A self-cleavage peptide (Ho et al., 2013). This tandem expression allows the selection of transformants exhibiting a higher transgene expression. Finally, Neupert et al. (2009) used UV mutagenesis to generate new $C$. reinhardtii strains presenting the advantage to increase the expression of nuclear transgenes. Indeed, using one of these strains (UVM4) transformed with the specific vector pcCAgLUC allowing the expression of the luciferase protein fused to the predicted signal peptide of the extracellular carbonic anhydrase 1 $(\mathrm{CAH} 1)$, Lauersen and coworkers demonstrated that the amount of secreted recombinant proteins could be significantly improved, reaching up to $10 \mathrm{mg}$ per liter of culture (Lauersen et al., 2013a). However, despite these significant achievements, efforts are still necessary to make $C$. reinhardtii competitive with $\mathrm{CHO}$ cell lines, for which yield between 5 and $10 \mathrm{~g} / \mathrm{L}$ of recombinant protein is currently obtained (Demain and Vaishnav, 2009).

\section{Other microalgae}

Recently, other microalgae species have also been shown to be of interest as new expression systems. For example, two recent studies reported the expression of a monoclonal human IgG antibody against the Hepatitis $B$ and its respective antigen in the diatom P. tricornutum. This antibody was either secreted in the culture medium or expressed in fusion to a DDEL (instead of KDEL which is used as a standard ER retention signal in other eukaryotes) sequence allowing its retention within the endoplasmic reticulum (ER) of Phaeodactylum tricornutum (Hempel et al., 2011b; Hempel and Maier, 2012). In contrast to C. reinhardtii, the codon usage in $P$. tricornutum is much closer to that of human (Heitzer et al., 2007), which could give advantage to this diatom for the production of biopharmaceuticals. In P. tricornutum, nuclear expression of transgenes is usually mediated through the promoter of the FCPA gene which encodes the fucoxanthin chlorophyll a/c binding protein (Apt et al., 1996; Zaslavskaia et al., 2000) or through the nitrate reductase promoter which is induced when ammonium is replaced by nitrates as nitrogen source in the culture medium (Poulsen and Kröger, 2005; Gonzalez et al., 2011; Hempel et al., 2011b; Hempel and Maier, 2012; Stork et al., 2012). This specific nitrate reductase inducible promoter was used to express the fully-assembled human IgG antibody against Hepatitis B leading to $1.5-2.5 \mathrm{mg}$ of recombinant antibody per liter of culture medium depending of the different clones (Hempel and Maier, 2012) and $21 \mathrm{mg}$ per gram of algal dry weight for the ER-retained form of the antibody (Hempel et al., 2011b).

Expression of commercially relevant proteins in other species of microalgae remains less reported, since tools for nuclear transformation are still missing. As for $C$. reinhardtii, the CaMV35S promoter has been shown to be efficient in several other green microalgae, including C. ellipsoidea (Jarvis and Brown, 1991; Chen et al., 2001; Kim et al., 2002), C. vulgaris (Hawkins and Nakamura, 1999), Haematococcus pluvialis (Kathiresan et al., 2009) and D. salina (Geng et al., 2003; Feng et al., 2009; Chai et al., 2013) but in most of the cases, the expression levels achieved remained low. Some studies reported the use of other foreign promoters to drive the nuclear expression of heterologous proteins in Chlorella sp., such as the C. reinhardtii RBCS2 promoter which has been used successfully in Chlorella ellipsoidea for transient expression of recombinant protein or resistance expression (Hawkins and Nakamura, 1999; Kim et al., 2002). In contrast, the ubiquitin maize promoter seems to be promising in Chlorella sp., since it allows the stable expression of a rabbit gene encoding for an $\alpha$-defensin (Bai et al., 2013). In some cases, the omega element of Tobacco Mosaic Virus (TMV) which is part of the $5^{\prime}$ UTR has been used to enhance translation efficiency (Chen et al., 2001), leading to a yield of about $11 \mathrm{mg} / \mathrm{L}$ of recombinant protein (Bai et al., 2013). This ubiquitin- $\Omega$ promoter was also successfully used in $D$. salina to stably express a gene encoding the hepatitis B surface antigen (Geng et al., 2003).

\section{EXPRESSION OF SECRETED THERAPEUTIC RECOMBINANT PROTEINS IN MICROALGAE}

As mentioned previously, most of the recombinant proteins that have been produced in $C$. reinhardtii so far were expressed in the chloroplast because of the high level of protein accumulation reached in this organelle. Thus, among the 20 recombinant proteins of industrial interest expressed in C. reinhardtii (for a recent review, see Rasala and Mayfield, 2014), only 3 of them have been expressed successfully through the nuclear genome: a xylanase (Rasala et al., 2012), an ice binding-protein (Lauersen et al., 2013b) and the secreted EPO (Eichler-Stahlberg et al., 2009). As the xylanase and ice binding-protein are not therapeutical proteins, we will not discuss them further in this review. In addition, by using the signal peptide of the $C$. reinhardtii gene ARS2 encoding a periplasmic arylsulfatase, the EPO has been produced in the culture medium of $C$. reinhardtii (Eichler-Stahlberg et al., 2009; Table 1). Furthermore, as previously indicated, Hempel and 
Table 1 | Post-translational modifications of biopharmaceuticals expressed in the secretory system of microalgae.

\begin{tabular}{|c|c|c|c|c|}
\hline Expressed protein & Promoter & $N$-glycosylation site ${ }^{a}$ & Glycosylation $^{\text {b }}$ & References \\
\hline \multicolumn{5}{|l|}{ IN C. REINHARDTII } \\
\hline Human EPO & Hsp70A/RbcS2 & Yes & Yes & Eichler-Stahlberg et al., 2009 \\
\hline $\begin{array}{l}\text { Monoclonal human IgG against } \\
\text { the Hepatitis B surface antigen }\end{array}$ & Nitrate reductase & Yes & Yes & $\begin{array}{l}\text { Hempel et al., } 2011 \text { b; Hempel } \\
\text { and Maier, } 2012\end{array}$ \\
\hline Hepatitis B surface antigen & Maize Ubiquitin $+\Omega$ TMV enhancer & Yes & No & Geng et al., 2003 \\
\hline
\end{tabular}

a Predicted N-glycosylation sites by bio-informatic analysis of the protein sequence.

${ }^{b}$ Experimental evidence of the presence of $N$-glycans attached to the $N$-glycosylation site.

Maier (2012) demonstrated the capability of P. tricornutum to synthesize and secrete a full length functional human IgG antibody against the Hepatitis B virus surface antigen. This study clearly demonstrates that diatoms are able to produce and correctly assemble complex proteins without affecting their biological activity (Table 1).

Little information is available on the post-translational modifications acquired by these microalgae-made therapeutic proteins in the secretory pathway. For example, the recombinant EPO expressed in C. reinhardtii exhibited a molecular mass of about $33 \mathrm{kDa}$ suggesting the presence of post-translational modifications such as the addition of glycans on the microalgae-made EPO. This is consistent with the fact that the EPO is known to possess $3 \mathrm{~N}$-glycosylation and one O-glycosylation sites (Table 1) (Lingg et al., 2012). Moreover, affinoblotting with concanavalin A, a lectin specific for oligomannoside structures (Fitchette et al., 2007), of the ER-resident recombinant IgG expressed in P. tricornutum also suggested that this microalgae-made antibody is glycosylated (Table 1) (Hempel et al., 2011b). However, no structural detailed analyses are reported regarding the glycans attached to those microalgae-made biopharmaceuticals. Since the $N$-glycosylation of biopharmaceuticals is critical for their halflife, stability and biological activity (for a recent review, see Lingg et al., 2012), it is therefore essential to characterize the $\mathrm{N}$-glycosylation process of secreted protein in microalgae.

\section{N-GLYCOSYLATION PATHWAYS IN MICROALGAE GENERAL ASPECTS OF $\boldsymbol{N}$-GLYCOSYLATION IN EUKARYOTES}

$N$-glycosylation is a major co- and post-translational modification of proteins in eukaryotes occurring in both the ER and the Golgi apparatus (Figure 1). In this process, a lipid-linked oligosaccharide is first assembled by the stepwise addition of monosaccharides on a dolichol pyrophosphate on the cytosolic face and then in the lumen of the ER (Burda and Aebi, 1999). This precursor is then transferred by the oligosaccharyltransferase (OST) complex onto the asparagine residues of the consensus Asn-X-Ser/Thr sequences of a protein (Burda and Aebi, 1999). In 3.5\% of the cases, other sequences like Asn-XCys, Asn-X-Val have been proven to be glycosylated on endogenous or recombinant protein produced both in mammals or plant cells (Gil et al., 2009; Zielinska et al., 2010; Matsui et al., 2011). The precursor is deglucosylated by the $\alpha$-glucosidases I and II and then reglucosylated by an UDP-glucose: glycoprotein glucosyltransferase (UGGT) to ensure the proper folding of the nascent protein through its interaction with ER-resident chaperones, such as calnexin and calreticulin. These ER events are conserved in eukaryotes because they are crucial for efficient protein folding and oligomerization (Helenius and Aebi, 2001). In contrast, evolutionary adaptation of $N$-glycan processing in the Golgi apparatus has given rise to a variety of organismspecific complex structures (Varki, 2011). First, $\alpha$-mannosidases degrade the oligosaccharide precursor into oligomannosides ranging from Man ${ }_{9} \mathrm{GlcNAc}_{2}$ to $\mathrm{Man}_{5} \mathrm{GlcNAc}_{2}$ (Man-9 to Man-5). $N$-acetylglucosaminyltransferase I (GnT I) then transfers a first $N$-acetylglucosaminyl (GlcNAc) residue on Man-5 and initiates the synthesis of a large variety of structurally different complextype $N$-glycans. In this GnT I-dependent $N$-glycan maturation, the processing continues by the removal of two mannosyl residues and the transfer of a second terminal GlcNAc residue, thus resulting in the synthesis of a core $\mathrm{GlcNAc}_{2} \mathrm{Man}_{3} \mathrm{GlCNAc}_{2}$ which are common to mammals and all land plants studied so far (Lerouge et al., 1998; Wilson et al., 2001; Gomord et al., 2010; Varki, 2011) (Figure 1). This core is then decorated by the action of a specific repertoire of glycosyltransferases that differ from one organism to another. As a consequence, mature proteins leaving the secretory pathway carry organism-specific complex $N$-glycans allowing the protein to acquire a set of glycan-mediated biological functions (Varki, 1993; Gagneux and Varki, 1999). For instance, in mammals, most secreted proteins in blood circulation carry biantennary $N$-glycans decorated with $\alpha(1,6)$-fucose residues and terminal sialic acids that impact either the protein activity or protein half-life (Figure 1; Lingg et al., 2012). In contrast, plant $\mathrm{N}$-glycans are mainly of biantennary complex type $\mathrm{N}$-glycan carrying a core- $\beta(1,2)$-xylose; a core $\alpha(1,3)$-fucose and eventually terminal Lewis a antennae (Lerouge et al., 1998; Wilson et al., 2001).

By comparison with data available in pluricellular eukaryotes, information concerning protein $\mathrm{N}$-glycosylation in microalgae remains very limited. A few studies using lectin blot analysis or enzymatic sequencing suggested that proteins secreted by green microalgae carry mainly oligomannosides or complex $N$-glycans having a core xylose residue (Balshüsemann and Jaenicke, 1990; Grunow et al., 1993; Gödel et al., 2000). More recently, a cell wall glycoprotein from the red microalgae Porphyridium sp. was 


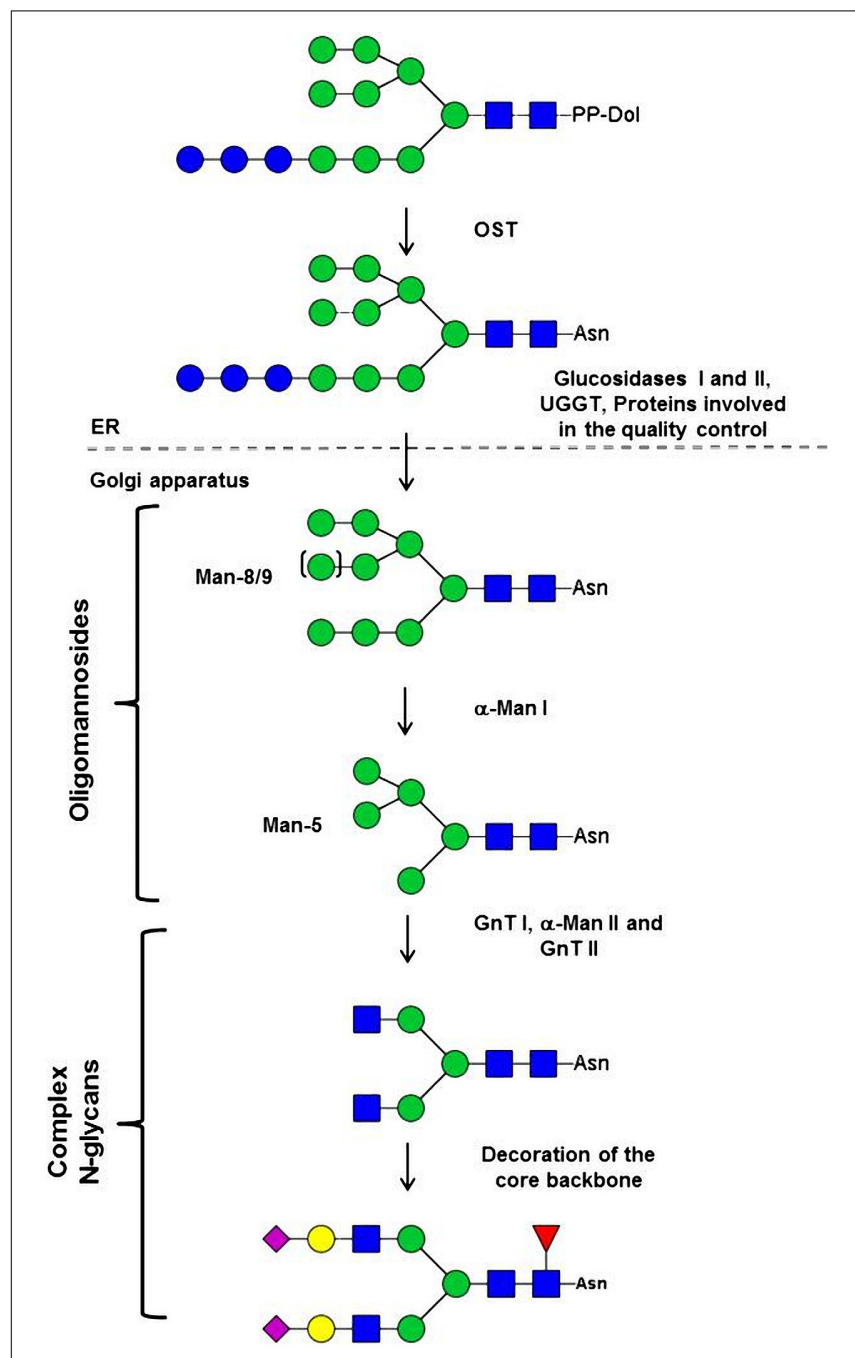

FIGURE 1 | Mammalian $\boldsymbol{N}$-glycosylation pathway. This pathway starts in the endoplasmic reticulum (ER) and ends in the Golgi apparatus where the major maturation steps lead to sialylated and fucosylated biantennary protein $N$-linked glycans. The $N$-glycan structures presented here are annotated according to the symbolic nomenclature adopted by the Consortium for Functional Glycomics (Varki et al., 2009). PP-Dol: Pyrophosphate Dolichol; OST: oligosaccharyltransferase; Asn, asparagine; UGGT, UDP-glucose glycoprotein glucosyltransferase; $\alpha$-Man, $\alpha$-mannosidase; GnT, N-acetylglucosaminyltransferase; Man-8/9, oligomannoside bearing 8/9 mannose residues; Man-5, oligomannoside bearing 5 mannose residues. $O$ Mannose $\bigcirc$ Glucose $\bigcirc$ Galactose $\diamond$ Sialic acid $\triangle$ Fucose $\square$ N-acetylglucosamine.

found to carry Man-8 and Man-9 oligomannosides containing 6$O$-methyl mannoses and substituted by one or two xylose residues (Levy-Ontman et al., 2011).

\section{STRUCTURAL INVESTIGATION OF GLYCAN N-LINKED TO MICROALGAE PROTEINS OF CHLAMYDOMONAS REINHARDTII AND PHAEODACTYLUM TRICORNUTUM}

Deeper insights into the structure of glycans $N$-linked to proteins secreted by C. reinhardtii (Mathieu-Rivet et al., 2013) and P. tricornutum (Baïet et al., 2011) have been recently reported and $N$-glycosylation pathways in these two microalgae dedicated to biotechnology applications have been proposed. These studies combined data resulting from the search for genes encoding putative enzymes involved in the $N$-glycosylation pathway in the genomic databases and data resulting from biochemical analysis of glycan $N$-linked to secreted proteins.

\section{Bio-informatic analysis}

In $C$. reinhardtii and $P$. tricornutum genomes, most of the genes encoding enzymes involved in the biosynthesis of the dolichol pyrophosphate-linked oligosaccharide on the cytosolic face and in the lumen of the ER, named Asparagine-Linked Glycosylation (ALG) (Weerapana and Imperiali, 2006), are predicted (Figure 2). Although some ALG were not clearly identified in the genomes, large oligomannosides up to Man-9 were found in both C. reinhardtii (Mathieu-Rivet et al., 2013) and P. tricornutum (Baïet et al., 2011) suggesting that the synthesis of the oligosaccharide precursor is similar to the one described in other eukaryotes. In addition to ALG, genes encoding subunits of the oligosaccharyltransferase were also identified in both genomes (Figure 2). Glucosidases I and II, as well as ER-resident UGGT and chaperones such as calreticulin, are also predicted. These proteins are key elements of the quality control of proteins occurring in the ER and are crucial for acquisition of the proper folding of the nascent glycoprotein (Figure 2).

After the transfer of the glycoprotein into the Golgi apparatus, maturation of $N$-linked glycans starts with the trimming of Man$9 /-8$ by $\alpha$-mannosidases I ( $\alpha$-Man I) that generate oligomannosides ranging from Man- 8 to Man-5. Genes encoding $\alpha$-Man I are predicted in C. reinhardtii and P. tricornutum genomes (Figure 2) suggesting that Golgi mediated trimming of oligommanosides also occurs in both microalgae. In higher eukaryotes including animals, insects and land plants, $N$-glycans are then processed by $\mathrm{GnT}$ I that transfers a first $N$-acetylglucosaminyl (GlcNAc) residue on the $\alpha(1,3)$-mannose arm of Man-5 (Figure 1). Thus, GnT I is a key enzyme since it is the first glycosyltransferase occurring in the Golgi apparatus in the GnT I-dependent pathway giving rise to complex $N$-glycans that are required for normal morphogenesis in pluricellular organisms (Ioffe and Stanley, 1994; Metzler et al., 1994). A sequence encoding for a GnT I is predicted in P. tricornutum (Baïet et al., 2011) but not in $C$. reinhardtii (Mathieu-Rivet et al., 2013) suggesting that $N$-linked glycans from these two microalgae could be processed in the Golgi apparatus according to two different pathways, referred to as $\mathrm{GnT}$ I-dependent and GnT I-independent pathways (Zhu et al., 2004; Crispin et al., 2006; Grass et al., 2011).

In both GnT I-dependent and independent pathways, the next steps mainly consist in the transfer of monosaccharides on the $N$-glycan core to synthesize highly diverse complex $N$-glycans. Among residues that are added to the core, fucosyl residues either $\alpha(1,3)$ - or $\alpha(1,6)$-linked to the proximal GlcNAc are commonly observed. In both microalgae, sequences encoding for putative $\alpha(1,3)$-fucosyltransferases were identified in the genomes (Baïet et al., 2011; Mathieu-Rivet et al., 2013). Search for other genes encoding for putative $N$-glycan processing enzymes revealed sequences exhibiting homologies with $\alpha$-Man II and GnT II in $P$. tricornutum but functional characterizations remain necessary to assess their enzymatic activities. 


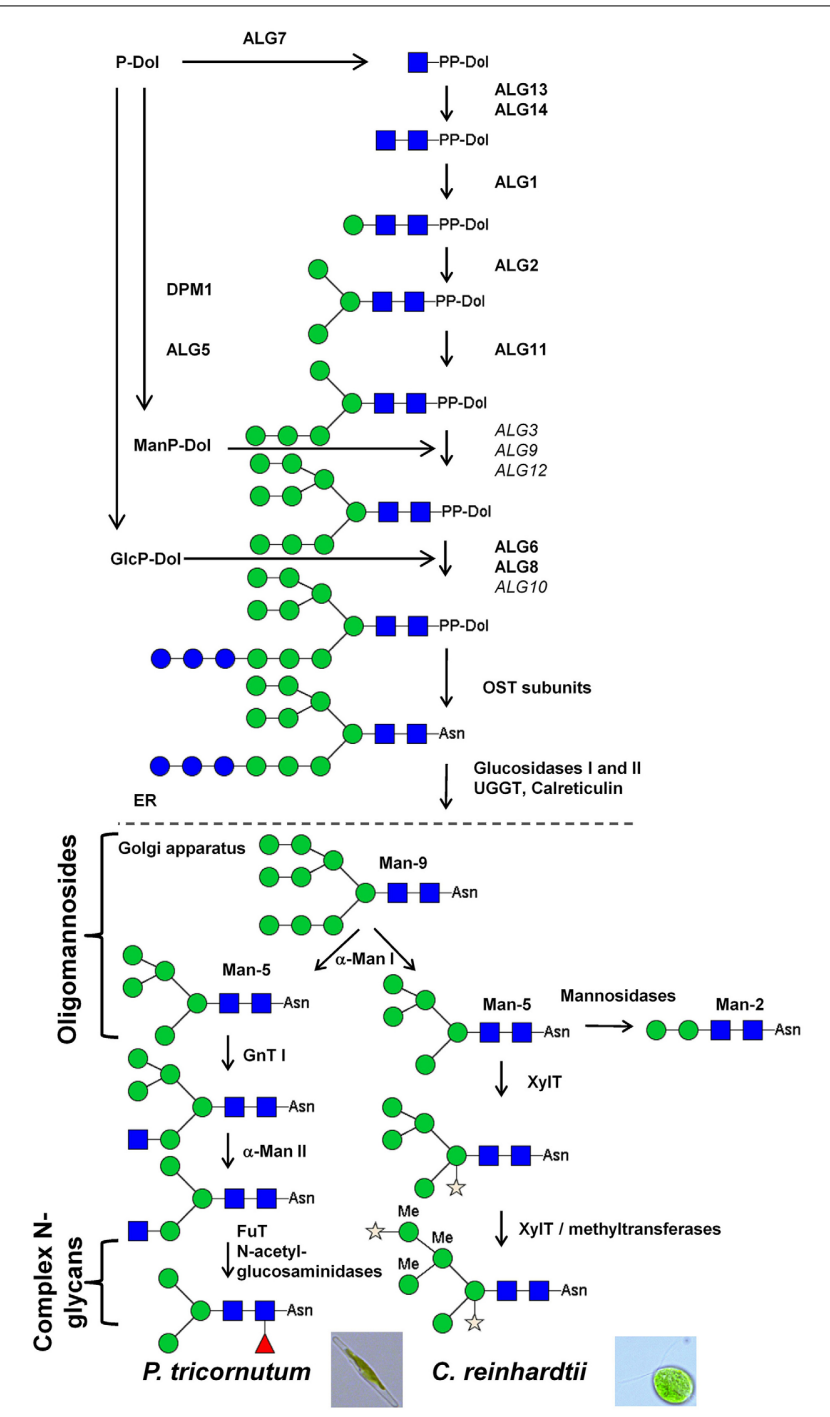

FIGURE 2 | Comparison of the N-glycosylation pathways in $\boldsymbol{P}$. tricornutum and $\boldsymbol{C}$. reinhardtii. In both microalgae, mature $N$-linked glycans have been structurally characterized. Genomic data are in agreement with the biochemical ones and are summarized in this figure. Sequences predicted in both $C$. reinhardtii and $P$. tricornutum genomes are written in bold. ALG10 in P. tricornutum genome and $A L G 3,6$ and 12 in $C$. reinhardtii genome have not been identified yet. The $\mathrm{N}$-glycan structures presented in this figure are annotated according to the symbolic nomenclature adopted by the Consortium for Functional Glycomics (Varki et al., 2009). DPM1: Dolichol-phosphate mannosyltransferase; ALG: Asparagine-Linked Glycosylation; PP-Dol: Pyrophosphate Dolichol; P-Dol: Dolichol phosphate; OST: oligosaccharyltransferase; Asn, asparagine; UGGT, UDP-glucose glycoprotein glucosyltransferase; GnT,

$\mathrm{N}$-acetylglucosaminyltransferase; $\alpha-M a n, \alpha-M a n n o s i d a s e ; ~ F u T$,

Fucosyltransferase; XylT, xylosyltransferase; Man-9, oligomannoside bearing 9 mannose residues; Man-5, oligomannoside bearing 5 mannose residue; Man-2, N-glycans bearing 2 mannose residues. Mannose Glucose $\bigcirc^{\text {Me }}$ Methyl mannose $\Delta$ Fucose $i$ Xylose

N-acetylglucosamine.

\section{Biochemical analysis}

A detailed glycomic analysis of C. reinhardtii proteins indicated that both secreted and membrane-bound proteins carry oligommanosides ranging from Man-2 to Man-5 and also complex
$\mathrm{N}$-glycans containing 6-O-methyl mannoses and substituted by one or two xylose residues (Figure 2) (Mathieu-Rivet et al., 2013). Similar complex structures have been previously found in a cell wall glycoprotein isolated from the red microalgae Porphyridium sp. (Levy-Ontman et al., 2011). However, the location of the xylose residue on the core $\mathrm{N}$-glycan differs in these two microalgae, since it is described to be linked to the chitobiose unit in Porphyridium rather than to $\mathrm{C} 2$ of the $\beta$-mannose as described in C. reinhardtii and as previously reported in land plants (Figure 2) (Lerouge et al., 1998). In agreement with bio-informatics data suggesting the absence of GnT I, these complex $\mathrm{N}$-glycans are likely to result from the transfer of xylose residues onto Man-5 oligomannosides in a GnT I-independent manner. Then, methylation of mannose residues is thought to occur after xylosylation of complex $N$-glycans in C. reinhardtii as proposed in Figure 2. Alternatively, Man-5 can be trimmed by mannosidases down to Man-2 (Figure 2). Although O-methyl mannose residues was previously reported in some eukaryotes (Staudacher, 2012), complex $N$-glycans from $C$. reinhardtii highly differ from glycans described in animals and land plants. We postulate that xylosylation and methylation of oligomannosides in these microalgae may protect glycoproteins against deglycosylating enzymes such as endoglycosidases or peptide $N$-glycosidases.

In contrast to complex $N$-glycans from $C$. reinhardtii, glycans $\mathrm{N}$-linked to proteins secreted by the diatom P. tricornutum can be processed through a GnT I-dependent pathway into partially fucosylated Man-3 (Figure 2) (Baïet et al., 2011). The GnT I gene predicted in the P. tricornutum genome was demonstrated to encode an active enzyme able to restore the maturation of $\mathrm{N}$-linked glycans into complex-type $\mathrm{N}$-glycans in the CHO Lec1 mutant, defective in its endogenous GnT I (Baït et al., 2011). The authors have proposed that this fucosylated $N$-linked glycan results from the addition of a terminal GlcNAc residue by GnT I on Man-5 followed by removal of two Man residues by an $\alpha$-Man II and the transfer of a fucose residue by the predicted $\alpha(1,3)$-FuT (Baïet et al., 2011). As illustrated in the proposed pathway depicted in Figure 2, the terminal GlcNAc introduced in the Golgi apparatus by the P. tricornutum GnT I is then likely removed in the secretory pathway by glucosaminidases as previously described in land plants and insect (Vitale and Chrispeels, 1984; Altmann et al., 1995). Efficient complementation of the CHO Lec1 mutant is the main argument supporting that this diatom processes its $\mathrm{N}$-glycans through a GnT I-dependent pathway. This result also indicates that the microalgae transferase is properly targeted to the Golgi apparatus when expressed in mammalian cells.

In these two studies performed on P. tricornutum and C. reinhardtii $\mathrm{N}$-glycan processing and as described for land plants (Séveno et al., 2004; Zeleny et al., 2006), no sialic acid residues were identified (Baïet et al., 2011; Mathieu-Rivet et al., 2013). Sialic acids are terminal residues of $\mathrm{O}$ - and $\mathrm{N}$-glycans that are specifically involved in many biological functions in mammals, such as the half-life of blood proteins and cell-cell adhesion processes (Figure 1) (Varki, 1993; Gagneux and Varki, 1999). 


\section{GLYCAN-REMODELING STRATEGIES IN MICROALGAE: PERSPECTIVES}

Differences in specificity of Golgi transferases and glycosidases between eukaryotes give rise to glycosylation profiles that differ between mammals and other eukaryotic host cells used as cell factories. As a consequence, glycans $N$-linked to recombinant proteins produced in plants, yeast or even in animal cells differ from the original therapeutic proteins. This may result in either a decrease or absence of biological activity. Furthermore, unsuitable $N$-glycan structures introduced by the expression system can induce immune responses in humans and generate adverse reactions (Van Beers and Bardor, 2012), as reported for $\alpha(1,3)$ Gal epitope or Neu5Gc on therapeutic drugs (Chung et al., 2008; Padler-Karavani et al., 2008). Similarly, plant synthesize $N$-glycans carrying immunogenic core-xylose and core- $\alpha(1,3)$ fucose that may induce immune responses in human treated with plant-made biopharmaceuticals (Bardor et al., 2003). In consequence, whatever the expression system that is considered, strategies have been carried out for the in vivo remodeling of the protein $\mathrm{N}$-glycans in order to obtain structures that meet pharmaceutical requirements. For instance, knock-out of endogenous genes involved in the transfer of core immunogenic epitopes have been carried out to engineer oligosaccharides synthesized by plant cell into human-compatible structures (Cox et al., 2006; Schähs et al., 2007; Strasser et al., 2008). Furthermore, knockin methodologies based on the expression in the host cells of mammalian enzyme have been developed to in vivo introduce missing glycan sequences. In plants, these efforts resulted in the production of plant-derived therapeutic proteins carrying $\mathrm{N}$ glycans similar to those found on human counterpart (Palacpac et al., 1999; Bakker et al., 2001, 2006; Misaki et al., 2006; Paccalet et al., 2007; Rouwendal et al., 2007; Castilho et al., 2008, 2010, 2013).

As reported in section Microalgae as Alternative Systems for Production of Recombinant Proteins, C. reinhardtii and P. tricornutum have been evaluated for their capacity to express therapeutic proteins. The recent characterization of glycans $\mathrm{N}$ linked to their secreted proteins allows the design of strategies to engineer their $\mathrm{N}$-glycan pathways for the production of humancompatible therapeutic proteins.

\section{MICROALGAE FOR THE PRODUCTION OF LYSOSOMAL PROTEINS}

Although complex $N$-glycans have been identified on proteins secreted by $C$. reinhardtii and $P$. tricornutum, most abundant oligosaccharides $N$-linked to proteins are oligomannosides ranging from Man-2 to Man-5 in C. reinhardtii (Mathieu-Rivet et al., 2013) and from Man-5 to Man-9 in P. tricornutum (Baïet et al., 2011) (Figure 2). These $N$-linked glycans are appropriate for the production of lysosomal therapeutics. For example, glucocerebrosidase is a glycoprotein drug administered intravenously into patients suffering from Gaucher's disease, a lysosomal storage disease. The effective targeting and internalization of this therapeutic drug into macrophages depend on terminal mannose residues of its $\mathrm{N}$-glycans which are recognized by macrophage cell surface mannose receptors (Van Patten et al., 2007). For treatment, exogenous glucocerebrosidase is administered intravenously into patients. The preparation of the current glucocerebrosidase expressed in $\mathrm{CHO}$ cells (Cerezyme ${ }^{\circledR}$ ) requires in vitro post-purification and exoglycosidase digestions to expose the trimannose core ( $\mathrm{Man}_{3} \mathrm{GlcNAc}_{2}$, Man-3) using a combination of at least three enzymes namely sialidase, galactosidase and $\mathrm{N}$-acetylglucosaminidase (Figure 3A). These in vitro glycoengineering steps increase considerably the production costs (Weinreb, 2008). Therefore, alternative expression systems that are capable of producing mannose terminated $\mathrm{N}$-glycans have been developed as safe and cost effective production methods. These include cultured carrot cells (Shaaltiel et al., 2007) and A. thaliana cgl transgenic plants (He et al., 2012). However, the analysis of the $\mathrm{N}$-glycan profiles of these glucocerebrosidase biosimilars revealed Man-5 with variable amount of Man-6 to Man-9 structures (for example low amount of Man 6 to Man-8 on glucocerebrosidase expressed in the Arabidopsis $c g l$ mutant). The presence of such structures required careful biosafety studies to evaluate the possible binding to serum mannose binding lectin (MBL) and immunogenicity (Van Patten et al., 2007; Grabowski et al., 2014). The results described for C. reinhardtii (MathieuRivet et al., 2013) suggest that this green microalgae could become in the future an appropriate platform for the production of a glucocerebrosidase bio-better which would naturally carry Man2 to Man-5 glycan structures without any in vitro trimming of mannose residues (Figure 2).

\section{MICROALGAE FOR THE PRODUCTION OF PROTEINS CARRYING HUMAN-COMPATIBLE COMPLEX-TYPE $\boldsymbol{N}$-GLYCANS}

Based on data reported in section N-glycosylation Pathways in Microalgae and Figure 2, the production in microalgae of

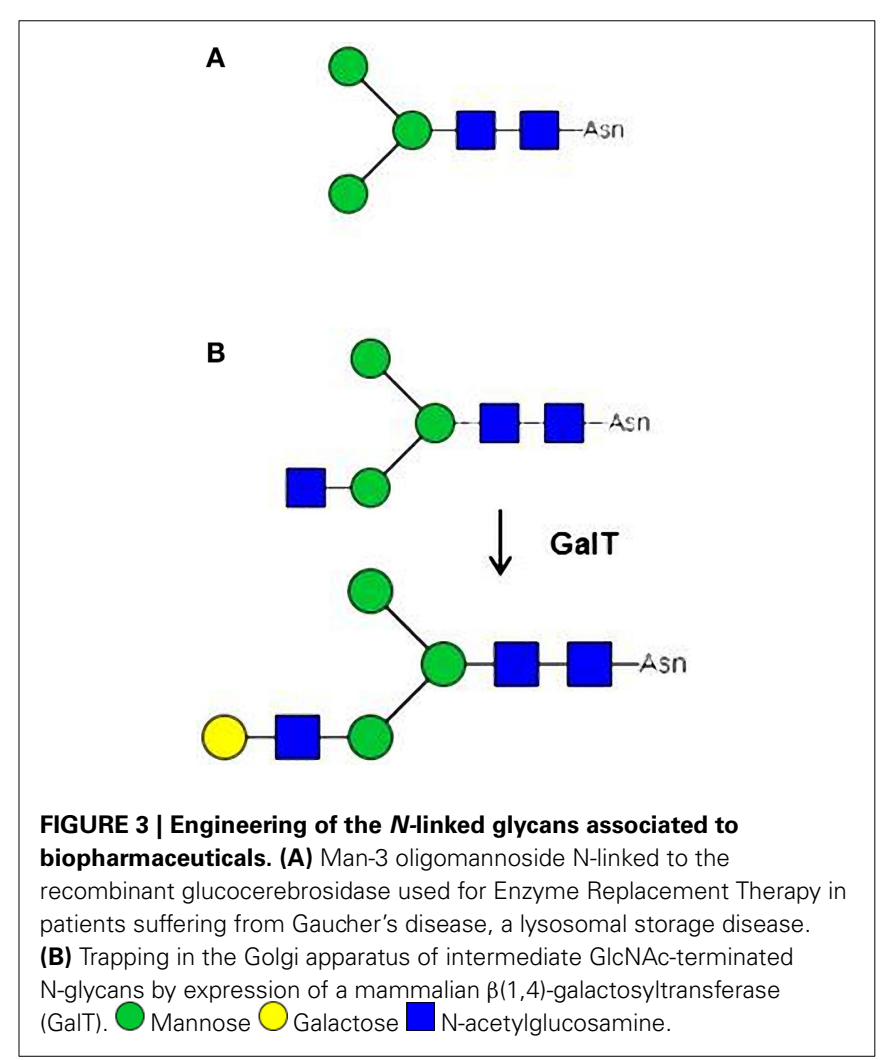


therapeutic proteins carrying human-like complex glycans will require intensive remodeling of their glycan pathways. Although no information is available on their immunogenicity, glycan epitopes identified on microalgae complex $N$-glycans will likely induce adverse effects in humans. Removal of these putative immunogenic glyco-epitopes, such as xylose and fucose residues, as well as methyl groups on mannose residues, will first require to identify gene encoding the corresponding glycosyltransferases and methyltransferases and then to carry out appropriate knockout strategies such as RNA interference; artificial microRNA which have already been developed in microalgae (Zhao et al., 2009; Cerutti et al., 2011). If putative FuT genes have already been identified because of their high homologies with plant $\alpha(1,3)$ FuT, the identification of sequences coding for xylosyltransferases (XylT) will be more tricky. Only the $\beta(1,2)$-XylT family involved in complex $N$-glycan biosynthesis in land plants have been biochemically characterized so far (Strasser et al., 2000). To date, no specific domain for XylT activity has been clearly identified and so, search by homology for XylT in microalgae genomes failed to clearly identify putative candidates.

As previously reported in land plants, "missing" residues on glycan $N$-linked to therapeutic proteins can be introduced by co-expression with appropriate glycosyltransferases. Results regarding the complementation of CHO Lec1 mutant by P. tricornutum GnT I (Baiet et al., 2011) showed that the targeting of Golgi glycosyltransferases is conserved between microalgae and higher eukaryotes. As a consequence, we can expect that the expression in microalgae of heterologous glycosyltransferases would allow the in vivo remodeling of their $N$-glycan pathways. This heterologous expression of glycosyltransferases should be particularly suitable for the remodeling of $N$-glycans in P. tricornutum because this diatom possesses a functional GnT I making its $N$-glycosylation pathway closer to the mammalian one (Figures 1, 2). The terminal GlcNAc introduced by GnT I constitute the starting point for the building of antennae in mammalian complex $N$-glycans (Figure 1). We postulated that in P. tricornutum this terminal GlcNAc is lost during the trafficking of the glycoprotein by action of $\mathrm{N}$-acetylglucosaminidases (Figure 2). However, the expression of a mammalian $\beta(1,4)$ galactosyltransferase in $P$. tricornutum would allow the transfer in the Golgi apparatus of a terminal Gal on the terminal GlcNAc, thus giving rise to a $\operatorname{Gal} \beta(1,4)$ GlcNAc extension that will protect this $\mathrm{N}$-acetylglucosamine residue introduced by $\mathrm{GnT}$ I from degradation by $\mathrm{N}$-acetylglucosaminidases downstream in the secretory pathway (Figure 3B). In addition, this extension corresponds to glycosidic motif found on some therapeutic proteins such as IgG. This strategy based on the trapping of intermediate GlcNAc-terminated $N$-glycans has already been successfully carried out in land plants (Bakker et al., 2001; Huether et al., 2005; Vézina et al., 2009) and insect cells (Hollister et al., 1998).

\section{SEARCH FOR MICROALGAE HAVING APPROPRIATE $\boldsymbol{N}$-GLYCOSYLATION PATHWAYS}

As in vivo engineering of the $N$-glycosylation pathways in C. reinhardtii and P. tricornutum may represent a tricky work, exploration for a microalga that exhibits a more appropriate protein glycosylation has to be considered. A first overview of protein
$N$-glycosylation in various microalgae species can be draw on the basis of public genomic databases. In addition to C. reinhardtii and $P$. tricornutum, more than 15 genomes from other microalgae are now available (e.g., Thalassossira pseudonana; Cyanidioschyzon merolae; Ostreococcus tauri and Ostreococcus lucimarinus; Micromonas pusilla; Chlorella vulgaris; Coccomyxa subellipsoidea; Nannochloropsis gaditana; Monoraphidium neglectum; Table 2) (Ambrust et al., 2004; Misumi et al., 2005; Palenik et al., 2007; Worden et al., 2009; Blanc et al., 2010, 2012; Radakovits et al., 2012; Vieler et al., 2012; Bogen et al., 2013). Searches for ALG genes and other sequences encoding proteins involved in the ER protein quality control indicated that enzymes of the ER machinery are predicted in all genomes suggesting that ER steps of the $N$-glycan pathway are conserved over the microalgae phyla as discussed recently in Levy-Ontman et al. (2014). With regard to Golgi events, Table 2 summarizes and reports the genes predicted to encode enzymes involved in the maturation of the $N$-glycans. As observed for $C$. reinhardtii and P. tricornutum, $\alpha$-mannosidases (CAZy GH 47) and $\alpha(1,3)$-fucosyltransferases (CAZy GT10) are predicted in most microalgae genomes. In contrast, genes encoding GnT I are not predicted in all genomes (Table 2; Baïet et al., 2011). For instance, as for C. reinhardtii, no GnT I was found in Volvox and Ostreococcus species whereas this key transferase is predicted in most other microalgae, including haptophytes and cryptophytes (Table 2; Baiet et al., 2011). As demonstrated in C. reinhardtii and $P$. tricornutum, this indicates that the Golgi maturation of protein $N$-linked glycans into complex oligosaccharides could either occur through a GnT I-dependent pathway or a GnT I-independent pathway in microalgae. In the context of microalgae-made biopharmaceutical production, this feature must be considered since the engineering of microalgae $N$-glycans into human compatible oligosaccharides would be facilitated if a GnT I-dependent machinery already exists in the strains selected as an expression system.

\section{CONCLUSIONS}

In conclusion, it can be considered that remodeling $N$-glycans as depicted in Figure 2 into human-compatible oligosaccharides would be a difficult challenge to attend. However, recent production in plants of therapeutic proteins carrying sialylated biantennary $N$-glycans demonstrates that such a glycan engineering can be achieved in a plant expression system (Castilho et al., 2013). It should also be noticed that only a few microalgae species have been investigated and so, data reported in this review should be considered as a starting point regarding protein glycosylation mechanisms occurring in these unicellular organisms and will serve as foundation for further glycobiology works. Efforts have now to be carried out to get more information concerning protein $\mathrm{N}$-glycan structures and their pathways in different phyla to identify microalgae species that are more appropriate for glycan remodeling strategies into human-like structures. This will also necessitate the characterization of the specificity of Golgi glycosyltransferases, such as $\alpha$-mannosidases and $\alpha(1,3)$ fucosyltransferases predicted in the microalgae genomes, to evaluate the efficiency in microalgae of heterologous expression of glycosyltransferases as well as to identify genes encoding transferases (methyltransferases and xylosyltransferases) involved in 
Table 2 | Genes predicted in microalgae genomes encoding proteins involved in $\mathbf{N}$-glycan Golgi maturation such as $\alpha$-Man I, mannosyl oligosaccharide alpha-1,2-mannosidase; GnT I, alpha-1,3-mannosyl-glycoprotein beta-1,2-N-acetylglucosaminyltransferase; $\alpha(1,3)$-FucT, core $\alpha(1,3)$-fucosyltransferase.

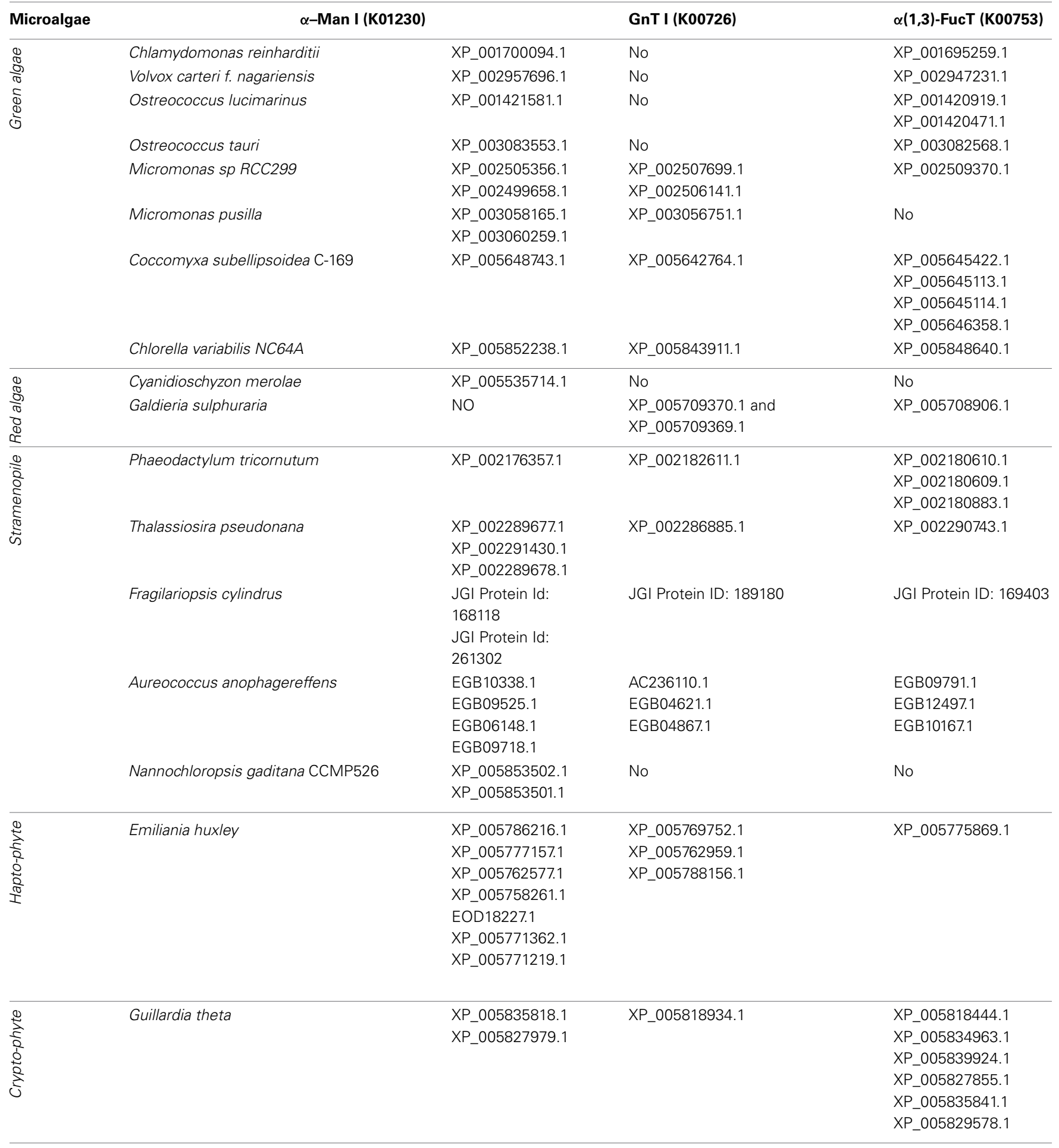

Sequences were retrieved using the KEGG orthology or by search with the protein's name (as defined in KEGG) in JGI, Phytozome or Genome at NCBI databanks. In addition, search for candidates was carried out by BLASTP or TBLASTN using human alpha-1,2-mannosidase protein sequences, rabbit GnTI (P27115) and Arabidopsis thaliana $\alpha$ (1,3)-FucT (Q9LJK1 and Q9FX97) as query sequences. 
the synthesis of putative immunogenic epitopes with the final goal to selectively inactivate their expression.

\section{AUTHOR CONTRIBUTION}

Elodie Mathieu-Rivet and Marie-Christine Kiefer-Meyer equally contributed to this work by drafting the manuscript and performing the genomic analyses of the microalgae genomes which are summarized in the Table 2 of the manuscript. Gaëtan Vanier, Clément Ovide and Carole Burel participated to the writing and took care of the figure drawing. Patrice Lerouge and Muriel Bardor came out with the idea of this review, participate to the writing and coordinated the efforts from the team prior to take care of the submission of the manuscript.

\section{ACKNOWLEDGMENTS}

We apologize to colleagues whose work is not cited due to space limitations. Part of the work described in this review was supported financially by the University of Rouen, France as well as the French National Agency for research, ANR, within the PLANTKBBE 2008 program in the frame of the ALGALGLYCO project. Finally, authors especially thank Dr Zhang Peiqing, Bioprocessing Technology Institute, Singapore and Prof. Driouich Azeddine, Laboratoire Glyco-MEV, University of Rouen, France for critical reading of this manuscript.

\section{REFERENCES}

Altmann, F., Schwihla, H., Staudacher, E., Glössl, J., and März, L. (1995). Insect cells contain an unusual, membrane-bound-N-acetylglucosaminidase probably involved in the processing of protein N-glycans. J. Biol. Chem. 270, 17344-17349. doi: 10.1074/jbc.270.29.17344

Ambrust, E. V., Berges, J., Bowler, C., Green, B., Martinez, D., Putnam, N., et al. (2004). The Genome of the Diatom Thalassiosira Pseudonana: Ecology, Evolution, and Metabolism. Lawrence Berkeley National Laboratory. Available online at: http://escholarship.org/uc/item/03j415ph [Accessed June 16, 2014].

Apt, K. E., Grossman, A. R., and Kroth-Pancic, P. G. (1996). Stable nuclear transformation of the diatomPhaeodactylum tricornutum. Mol. Gen. Genet. 252, 572-579.

Baïet, B., Burel, C., Saint-Jean, B., Louvet, R., Menu-Bouaouiche, L., Kiefer-Meyer, M.-C., et al. (2011). N-glycans of Phaeodactylum tricornutum diatom and functional characterization of its $\mathrm{N}$-acetylglucosaminyltransferase I enzyme. J. Biol. Chem. 286, 6152-6164. doi: 10.1074/jbc.M110.175711

Bai, L.-L., Yin, W.-B., Chen, Y.-H., Niu, L.-L., Sun, Y.-R., Zhao, S.-M., et al. (2013). A new strategy to produce a defensin: stable production of mutated NP-1 in nitrate reductase-deficient chlorella ellipsoidea. PLOS ONE 8:e54966. doi: 10.1371/journal.pone.0054966

Bakker, H., Bardor, M., Molthoff, J. W., Gomord, V., Elbers, I., Stevens, L. H., et al. (2001). Galactose-extended glycans of antibodies produced by transgenic plants. Proc. Natl. Acad. Sci. U.S.A. 98, 2899-2904. doi: 10.1073/pnas.031 419998

Bakker, H., Rouwendal, G. J., Karnoup, A. S., Florack, D. E., Stoopen, G. M., Helsper, J. P., et al. (2006). An antibody produced in tobacco expressing a hybrid $\beta$-1, 4-galactosyltransferase is essentially devoid of plant carbohydrate epitopes. Proc. Natl. Acad. Sci. U.S.A. 103, 7577-7582. doi: 10.1073/pnas.06008 79103

Balshüsemann, D., and Jaenicke, L. (1990). The oligosaccharides of the glycoprotein pheromone of Volvox carteri f. nagariensis Iyengar (Chlorophyceae). Eur. J. Biochem. 192, 231-237. doi: 10.1111/j.1432-1033.1990.tb19220.x

Bardor, M., Faveeuw, C., Fitchette, A.-C., Gilbert, D., Galas, L., Trottein, F., et al. (2003). Immunoreactivity in mammals of two typical plant glyco-epitopes, core $\alpha$ (1,3)-fucose and core xylose. Glycobiology 13, 427-434. doi: 10.1093/glycob/cwg024

Beer, L. L., Boyd, E. S., Peters, J. W., and Posewitz, M. C. (2009). Engineering algae for biohydrogen and biofuel production. Curr. Opin. Biotechnol. 20, 264-271. doi: 10.1016/j.copbio.2009.06.002
Blanc, G., Agarkova, I., Grimwood, J., Kuo, A., Brueggeman, A., Dunigan, D. D., et al. (2012). The genome of the polar eukaryotic microalga Coccomyxa subellipsoidea reveals traits of cold adaptation. Genome Biol. 13:R39. doi: 10.1186/gb-2012-13-5-r39

Blanc, G., Duncan, G., Agarkova, I., Borodovsky, M., Gurnon, J., Kuo, A., et al. (2010). The Chlorella variabilis NC64A genome reveals adaptation to photosymbiosis, coevolution with viruses, and cryptic sex. Plant Cell Online 22, 2943-2955. doi: 10.1105/tpc.110.076406

Bogen, C., Al-Dilaimi, A., Albersmeier, A., Wichmann, J., Grundmann, M., Rupp, O., et al. (2013). Reconstruction of the lipid metabolism for the microalga Monoraphidium neglectum from its genome sequence reveals characteristics suitable for biofuel production. BMC Genomics 14:926. doi: 10.1186/1471-216414-926

Burda, P., and Aebi, M. (1999). The dolichol pathway of N-linked glycosylation. Biochim. Biophys. Acta 1426, 239-257. doi: 10.1016/S0304-4165(98) 00127-5

Buyel, J. F., and Fischer, R. (2014). Downstream processing of biopharmaceutical proteins produced in plants: the pros and cons of flocculants. Bioengineered 5 , 138-142. doi: 10.4161/bioe.28061

Cadoret, J.-P., and Bernard, O. (2008). La production de biocarburant lipidique avec des microalgues: promesses et défis. J. Soc. Biol. 202, 201-211. doi: 10.1051/jbio:2008022

Castilho, A., Neumann, L., Gattinger, P., Strasser, R., Vorauer-Uhl, K., Sterovsky, T., et al. (2013). Generation of biologically active multi-sialylated recombinant human EPOFc in plants. PLOS ONE 8:e54836. doi: 10.1371/journal.pone.0054836

Castilho, A., Pabst, M., Leonard, R., Veit, C., Altmann, F., Mach, L., et al. (2008). Construction of a functional CMP-sialic acid biosynthesis pathway in Arabidopsis. Plant Physiol. 147, 331-339. doi: 10.1104/pp.108.117572

Castilho, A., Strasser, R., Stadlmann, J., Grass, J., Jez, J., Gattinger, P., et al. (2010). In planta protein sialylation through overexpression of the respective mammalian pathway. J. Biol. Chem. 285, 15923-15930. doi: 10.1074/jbc.M109. 088401

Cerutti, H., Johnson, A. M., Gillham, N. W., and Boynton, J. E. (1997). Epigenetic silencing of a foreign gene in nuclear transformants of Chlamydomonas. Plant Cell 9, 925-945. doi: 10.1105/tpc.9.6.925

Cerutti, H., Ma, X., Msanne, J., and Repas, T. (2011). RNA-mediated silencing in algae: biological roles and tools for analysis of gene function. Eukaryot Cell 10, 1164-1172. doi: 10.1128/EC.05106-11

Chai, X.-J., Chen, H.-X., Xu, W.-Q., and Xu, Y.-W. (2013). Expression of soybean Kunitz trypsin inhibitor gene SKTI in Dunaliella salina. J. Appl. Phycol. 25, 139-144. doi: 10.1007/s10811-012-9847-8

Chen, Y., Wang, Y., Sun, Y., Zhang, L., and Li, W. (2001). Highly efficient expression of rabbit neutrophil peptide-1 gene in Chlorella ellipsoidea cells. Curr. Genet. 39, 365-370. doi: 10.1007/s002940100205

Chung, C. H., Mirakhur, B., Chan, E., Le, Q.-T., Berlin, J., Morse, M., et al. (2008). Cetuximab-induced anaphylaxis and IgE specific for galactose- $\alpha-1,3$-galactose. New Engl. J. Med. 358, 1109-1117. doi: 10.1056/NEJMoa074943

Colgan, R., Atkinson, C. J., Paul, M., Hassan, S., Drake, P. M. W., Sexton, A. L., et al. (2010). Optimisation of contained Nicotiana tabacum cultivation for the production of recombinant protein pharmaceuticals. Transgenic Res. 19, 241-256. doi: 10.1007/s11248-009-9303-y

Cox, K. M., Sterling, J. D., Regan, J. T., Gasdaska, J. R., Frantz, K. K., Peele, C. G., et al. (2006). Glycan optimization of a human monoclonal antibody in the aquatic plant Lemna minor. Nat. Biotechnol. 24, 1591-1597. doi: $10.1038 /$ nbt 1260

Crispin, M., Harvey, D. J., Chang, V. T., Yu, C., Aricescu, A. R., Jones, E. Y., et al. (2006). Inhibition of hybrid- and complex-type glycosylation reveals the presence of the GlcNAc transferase I-independent fucosylation pathway. Glycobiology 16, 748-756. doi: 10.1093/glycob/cwj119

Decker, E. L., and Reski, R. (2012). Glycoprotein production in moss bioreactors. Plant Cell Rep. 31, 453-460. doi: 10.1007/s00299-011-1152-5

Demain, A. L., and Vaishnav, P. (2009). Production of recombinant proteins by microbes and higher organisms. Biotechnol. Adv. 27, 297-306. doi: 10.1016/j.biotechadv.2009.01.008

Demurtas, O. C., Massa, S., Ferrante, P., Venuti, A., Franconi, R., and Giuliano, G. (2013). A chlamydomonas-derived human papillomavirus 16 E7 vaccine induces specific tumor protection. PLOS ONE 8:e61473. doi: 10.1371/journal.pone.0061473 
De Muynck, B., Navarre, C., and Boutry, M. (2010). Production of antibodies in plants: status after twenty years. Plant Biotechnol. J. 8, 529-563. doi: 10.1111/j.1467-7652.2009.00494.x

Díaz-Santos, E., Vega, M., Vila, M., Vigara, J., and León, R. (2013). Efficiency of Different Heterologous Promoters in the Unicellular Microalga Chlamydomonas Reinhardtii. Available online at: http://onlinelibrary.wiley.com/doi/10.1002/ btpr.1690/full [Accessed December 1, 2013].

Drake, P. M. W., Barbi, T., Sexton, A., McGowan, E., Stadlmann, J., Navarre, C., et al. (2009). Development of rhizosecretion as a production system for recombinant proteins from hydroponic cultivated tobacco. FASEB J. 23, 3581-3589. doi: 10.1096/fj.09-131771

Eichler-Stahlberg, A., Weisheit, W., Ruecker, O., and Heitzer, M. (2009). Strategies to facilitate transgene expression in Chlamydomonas reinhardtii. Planta 229, 873-883. doi: 10.1007/s00425-008-0879-x

Feng, S., Xue, L., Liu, H., and Lu, P. (2009). Improvement of efficiency of genetic transformation for Dunaliella salina by glass beads method. Mol. Biol. Rep. 36, 1433-1439. doi: 10.1007/s11033-008-9333-1

Fischer, N., and Rochaix, J.-D. (2001). The flanking regions of PsaD drive efficient gene expression in the nucleus of the green alga Chlamydomonas reinhardtii. Mol. Genet. Genomics 265, 888-894. doi: 10.1007/s004380100485

Fitchette, A.-C., Dinh, O. T., Faye, L., and Bardor, M. (2007). "Plant Proteomics and Glycosylation," in Plant Proteomics Methods in Molecular Biology, eds H. Thiellement, M. Zivy, C. Damerval, and V. Méchin (Humana Press), 317-342. Available online at: http://link.springer.com/protocol/10.1385/1-59745-227-0 \%3A317 [Accessed June 16, 2014].

Fuhrmann, M., Oertel, W., and Hegemann, P. (1999). A synthetic gene coding for the green fluorescent protein (GFP) is a versatile reporter in Chlamydomonas reinhardtii. Plant J. 19, 353-361. doi: 10.1046/j.1365-313X.1999. 00526.x

Gagneux, P., and Varki, A. (1999). Evolutionary considerations in relating oligosaccharide diversity to biological function. Glycobiology 9, 747-755. doi: 10.1093/glycob/9.8.747

Geng, D., Wang, Y., Wang, P., Li, W., and Sun, Y. (2003). Stable expression of hepatitis B surface antigen gene in Dunaliella salina (Chlorophyta). J. Appl. Phycol. 15, 451-456. doi: 10.1023/B:JAPH.0000004298.89183.e5

Gil, G.-C., Velander, W. H., and Van Cott, K. E. (2009). N-glycosylation microheterogeneity and site occupancy of an Asn-X-Cys sequon in plasma-derived and recombinant Protein C. Proteomics 9, 2555-2567. doi: 10.1002/pmic. 200800775

Gödel, S., Becker, B., and Melkonian, M. (2000). Flagellar membrane proteins of Tetraselmis striata butcher (Chlorophyta). Protist 151, 147-159. doi: 10.1078/1434-4610-00015

Gomord, V., Fitchette, A.-C., Menu-Bouaouiche, L., Saint-Jore-Dupas, C., Plasson, C., Michaud, D., et al. (2010). Plant-specific glycosylation patterns in the context of therapeutic protein production. Plant Biotechnol. J. 8, 564-587. doi: 10.1111/j.1467-7652.2009.00497.x

Gonzalez, N. H., Felsner, G., Schramm, F. D., Klingl, A., Maier, U.-G., and Bolte, K. (2011). A single peroxisomal targeting signal mediates matrix protein import in diatoms. PLoS ONE 6:e25316. doi: 10.1371/journal.pone.0025316

Grabowski, G. A., Golembo, M., and Shaaltiel, Y. (2014). Taliglucerase alfa: an enzyme replacement therapy using plant cell expression technology. Mol. Genet. Metab. 112, 1-8. doi: 10.1016/j.ymgme.2014.02.011

Grass, J., Pabst, M., Kolarich, D., Poltl, G., Leonard, R., Brecker, L., et al. (2011). Discovery and structural characterization of fucosylated oligomannosidic N-glycans in mushrooms. J. Biol. Chem. 286, 5977-5984. doi: 10.1074/jbc.M110.191304

Grunow, A., Becker, B., and Melkonian, M. (1993). Isolation and characterization of the Golgi apparatus of a flagellate scaly green alga. Eur. J. Cell Biol. 61, 10-10.

Harris, E. H. (2009). The Chlamydomonas Sourcebook: Introduction to Chlamydomonas and Its Laboratory Use. Oxford: Academic Press.

Hawkins, R. L., and Nakamura, M. (1999). Expression of human growth hormone by the eukaryotic alga, Chlorella. Curr. Microbiol. 38, 335-341. doi: 10.1007/PL00006813

He, X., Galpin, J. D., Tropak, M. B., Mahuran, D., Haselhorst, T., von Itzstein, M., et al. (2012). Production of active human glucocerebrosidase in seeds of Arabidopsis thaliana complex-glycan-deficient (cgl) plants. Glycobiology 22, 492-503. doi: 10.1093/glycob/cwr157

Heitzer, M., Eckert, A., Fuhrmann, M., and Griesbeck, C. (2007). "Influence of codon bias on the expression of foreign genes in microalgae," in
Transgenic Microalgae as Green Cell Factories (Springer), 46-53. Available online at: http://link.springer.com/chapter/10.1007/978-0-387-75532-8_5 [Accessed December 1, 2013].

Helenius, A., and Aebi, M. (2001). Intracellular functions of N-linked glycans. Science 291, 2364-2369. doi: 10.1126/science.291.5512.2364

Hempel, F., Bozarth, A. S., Lindenkamp, N., Klingl, A., Zauner, S., Linne, U., et al. (2011a). Microalgae as bioreactors for bioplastic production. Microb. Cell Fact. 10:81. doi: 10.1186/1475-2859-10-81

Hempel, F., Lau, J., Klingl, A., and Maier, U. G. (2011b). Algae as protein factories: expression of a human antibody and the respective antigen in the diatom phaeodactylum tricornutum. PLOS ONE 6:e28424. doi: 10.1371/journal.pone.0028424

Hempel, F., and Maier, U. G. (2012). An engineered diatom acting like a plasma cell secreting human IgG antibodies with high efficiency. Microb. Cell Fact. 11:126. doi: 10.1186/1475-2859-11-126

Ho, S. C. L., Bardor, M., Li, B., Lee, J. J., Song, Z., Tong, Y. W., et al. (2013). Comparison of internal ribosome entry site (IRES) and Furin-2A (F2A) for monoclonal antibody expression level and quality in CHO cells. PLoS ONE 8:e63247. doi: 10.1371/journal.pone.0063247

Hollister, J. R., Shaper, J. H., and Jarvis, D. L. (1998). Stable expression of mammalian beta 1,4-galactosyltransferase extends the N-glycosylation pathway in insect cells. Glycobiology 8, 473-480. doi: 10.1093/glycob/8.5.473

Hossler, P., Khattak, S. F., and Li, Z. J. (2009). Optimal and consistent protein glycosylation in mammalian cell culture. Glycobiology 19, 936-949. doi: 10.1093/glycob/cwp079

Huang, C.-J., Lin, H., and Yang, X. (2012). Industrial production of recombinant therapeutics in Escherichia coli and its recent advancements. J. Ind. Microbiol. Biotechnol. 39, 383-399. doi: 10.1007/s10295-011-1082-9

Huether, C. M., Lienhart, O., Baur, A., Stemmer, C., Gorr, G., Reski, R., et al. (2005). Glyco-Engineering of Moss Lacking Plant-Specific Sugar Residues. Plant Biol. 7, 292-299. doi: 10.1055/s-2005-837653

Ioffe, E., and Stanley, P. (1994). Mice lacking N-acetylglucosaminyltransferase I activity die at mid-gestation, revealing an essential role for complex or hybrid N-linked carbohydrates. Proc. Natl. Acad. Sci. U.S.A. 91, 728-732. doi: 10.1073/pnas.91.2.728

Jarvis, E. E., and Brown, L. M. (1991). Transient expression of firefly luciferase in protoplasts of the green alga Chlorella ellipsoidea. Curr. Genet. 19, 317-321. doi: 10.1007/BF00355062

Kathiresan, S., Chandrashekar, A., Ravishankar, G. A., and Sarada, R. (2009). Agrobacterium_mediated transformation in the green alga Haematococcus pluvilais (Chlorophyceae, Volvocales) 1. J. Phycol. 45, 642-649. doi: 10.1111/j.1529-8817.2009.00688.x

Kim, D.-H., Kim, Y. T., Cho, J. J., Bae, J.-H., Hur, S.-B., Hwang, I., et al. (2002). Stable integration and functional expression of flounder growth hormone gene in transformed microalga, Chlorella ellipsoidea. Mar. Biotechnol. 4, 63-73. doi: 10.1007/s1012601-0070-x

Kindle, K. L. (1998). "High-frequency nuclear transformation of Chlamydomonas reinhardtii," in Methods in Enzymology Photosynthesis: Molecular Biology of Energy Capture, ed L. McIntosh (Academic Press), 27-38. Available online at: http://www.sciencedirect.com/science/article/pii/S0076687998970057 [Accessed January 20, 2014].

Kumar, A., Falcao, V. R., and Sayre, R. T. (2013). Evaluating nuclear transgene expression systems in Chlamydomonas reinhardtii. Algal Res. 2, 321-332. doi: 10.1016/j.algal.2013.09.002

Lam, M. K., and Lee, K. T. (2012). Microalgae biofuels: a critical review of issues, problems and the way forward. Biotechnol. Adv. 30, 673-690. doi: 10.1016/j.biotechadv.2011.11.008

Lauersen, K. J., Berger, H., Mussgnug, J. H., and Kruse, O. (2013a). Efficient recombinant protein production and secretion from nuclear transgenes in Chlamydomonas reinhardtii. J. Biotechnol. 167, 101-110. doi: 10.1016/j.jbiotec.2012.10.010

Lauersen, K. J., Vanderveer, T. L., Berger, H., Kaluza, I., Mussgnug, J. H., Walker, V. K., et al. (2013b). Ice recrystallization inhibition mediated by a nuclearexpressed and -secreted recombinant ice-binding protein in the microalga Chlamydomonas reinhardtii. Appl. Microbiol. Biotechnol. 97, 9763-9772. doi: 10.1007/s00253-013-5226-x

Lerouge, P., Cabanes-Macheteau, M., Rayon, C., Fischette-Lain,é, A.-C., Gomord, V., and Faye, L. (1998). "N-glycoprotein biosynthesis in plants: recent developments and future trends," in Protein Trafficking in 
Plant Cells (Springer), 31-48. Available online at: http://link.springer. com/chapter/10.1007/978-94-011-5298-3_2 [Accessed December 1, 2013].

Levy-Ontman, O., Arad, S. M., Harvey, D. J., Parsons, T. B., Fairbanks, A., and Tekoah, Y. (2011). Unique N-glycan moieties of the $66-\mathrm{kDa}$ cell wall glycoprotein from the red microalga Porphyridium sp. J. Biol. Chem. 286, 21340-21352. doi: 10.1074/jbc.M110.175042

Levy-Ontman, O., Fisher, M., Shotland, Y., Weinstein, Y., Tekoah, Y., and Arad, S. M. (2014). Genes involved in the endoplasmic reticulum N-glycosylation pathway of the red microalga Porphyridium sp.: a bioinformatic study. Int. J. Mol. Sci. 15, 2305-2326. doi: 10.3390/ijms15022305

Lingg, N., Zhang, P., Song, Z., and Bardor, M. (2012). The sweet tooth of biopharmaceuticals: importance of recombinant protein glycosylation analysis. Biotechnol. J. 7, 1462-1472. doi: 10.1002/biot.201200078

Lumbreras, V., Stevens, D. R., and Purton, S. (1998). Efficient foreign gene expression in Chlamydomonas reinhardtii mediated by an endogenous intron. Plant J. 14, 441-447. doi: 10.1046/j.1365-313X.1998.00145.x

Mata, T. M., Martins, A. A., and Caetano, N. S. (2010). Microalgae for biodiesel production and other applications: a review. Renew. Sust. Energ. Rev. 14, 217-232. doi: 10.1016/j.rser.2009.07.020

Mathieu-Rivet, E., Scholz, M., Arias, C., Dardelle, F., Schulze, S., Le Mauff, F., et al. (2013). Exploring the N-glycosylation pathway in chlamydomonas reinhardtii unravels novel complex structures. Mol. Cell. Proteomics 12, 3160-3183. doi: 10.1074/mcp.M113.028191

Matsui, T., Takita, E., Sato, T., Kinjo, S., Aizawa, M., Sugiura, Y., et al. (2011). Nglycosylation at noncanonical Asn-X-Cys sequences in plant cells. Glycobiology 21, 994-999. doi: 10.1093/glycob/cwq198

Maxmen, A. (2012). Drug-making plant blooms. Nature 485, 160-160. doi: $10.1038 / 485160 \mathrm{a}$

Mayfield, S. P., Franklin, S. E., and Lerner, R. A. (2003). Expression and assembly of a fully active antibody in algae. Proc. Natl. Acad. Sci. 100, 438-442. doi: 10.1073/pnas.0237108100

Merchant, S. S., Kropat, J., Liu, B., Shaw, J., and Warakanont, J. (2012). TAG, You're it! Chlamydomonas as a reference organism for understanding algal triacylglycerol accumulation. Curr. Opin. Biotechnol. 23, 352-363. doi: 10.1016/j.copbio.2011.12.001

Merchant, S. S., Prochnik, S. E., Vallon, O., Harris, E. H., Karpowicz, S. J., Witman, G. B., et al. (2007). The Chlamydomonas genome reveals the evolution of key animal and plant functions. Science 318, 245-250. doi: 10.1126/science.1143609

Metzler, M., Gertz, A., Sarkar, M., Schachter, H., Schrader, J. W., and Marth, J. D. (1994). Complex asparagine-linked oligosaccharides are required for morphogenic events during post-implantation development. EMBO J. 13, 2056-2065.

Misaki, R., Fujiyama, K., and Seki, T. (2006). Expression of human CMP-Nacetylneuraminic acid synthetase and CMP-sialic acid transporter in tobacco suspension-cultured cell. Biochem. Biophys. Res. Commun. 339, 1184-1189. doi: 10.1016/j.bbrc.2005.11.130

Misumi, O., Matsuzaki, M., Nozaki, H., Miyagishima, S., Mori, T., Nishida, K., et al. (2005). Cyanidioschyzon merolae genome. A tool for facilitating comparable studies on organelle biogenesis in photosynthetic eukaryotes. Plant Physiol. 137, 567-585. doi: 10.1104/pp.104.053991

Neupert, J., Karcher, D., and Bock, R. (2009). Generation of Chlamydomonas strains that efficiently express nuclear transgenes. Plant J. 57, 1140-1150. doi: 10.1111/j.1365-313X.2008.03746.x

Paccalet, T., Bardor, M., Rihouey, C., Delmas, F., Chevalier, C., D’Aoust, M.-A., et al. (2007). Engineering of a sialic acid synthesis pathway in transgenic plants by expression of bacterial Neu5Ac-synthesizing enzymes. Plant Biotechnol. J. 5, 16-25. doi: 10.1111/j.1467-7652.2006.00211.x

Padler-Karavani, V., Yu, H., Cao, H., Chokhawala, H., Karp, F., Varki, N., et al. (2008). Diversity in specificity, abundance, and composition of anti-Neu5Gc antibodies in normal humans: potential implications for disease. Glycobiology 18, 818-830. doi: 10.1093/glycob/cwn072

Palacpac, N. Q., Yoshida, S., Sakai, H., Kimura, Y., Fujiyama, K., Yoshida, T., et al. (1999). Stable expression of human $\beta 1$, 4-galactosyltransferase in plant cells modifies N-linked glycosylation patterns. Proc. Natl. Acad. Sci. U.S.A. 96, 4692-4697. doi: 10.1073/pnas.96.8.4692

Palenik, B., Grimwood, J., Aerts, A., Rouzé, P., Salamov, A., Putnam, N., et al. (2007). The tiny eukaryote Ostreococcus provides genomic insights into the paradox of plankton speciation. Proc. Natl. Acad. Sci. U.S.A. 104, 7705-7710. doi: 10.1073/pnas.0611046104
Park, S., Lee, Y., Lee, J.-H., and Jin, E. (2013). Expression of the high lightinducible Dunaliella LIP promoter in Chlamydomonas reinhardtii. Planta 238, 1147-1156. doi: 10.1007/s00425-013-1955-4

Parsons, J., Altmann, F., Arrenberg, C. K., Koprivova, A., Beike, A. K., Stemmer, C., et al. (2012). Moss-based production of asialo-erythropoietin devoid of Lewis A and other plant-typical carbohydrate determinants. Plant Biotechnol. J. 10, 851-861. doi: 10.1111/j.1467-7652.2012.00704.x

Potvin, G., and Zhang, Z. (2010). Strategies for high-level recombinant protein expression in transgenic microalgae: a review. Biotechnol. Adv. 28, 910-918. doi: 10.1016/j.biotechadv.2010.08.006

Poulsen, N., and Kröger, N. (2005). A new molecular tool for transgenic diatoms. Febs J. 272, 3413-3423. doi: 10.1111/j.1742-4658.2005.04760.x

Radakovits, R., Jinkerson, R. E., Fuerstenberg, S. I., Tae, H., Settlage, R. E., Boore, J. L., et al. (2012). Draft genome sequence and genetic transformation of the oleaginous alga Nannochloropis gaditana. Nat. Commun. 3:686. doi: 10.1038/ncomms 1688

Rasala, B. A., Lee, P. A., Shen, Z., Briggs, S. P., Mendez, M., and Mayfield, S. P. (2012). Robust expression and secretion of Xylanasel in chlamydomonas reinhardtii by fusion to a selection gene and processing with the FMDV 2A peptide. PLoS ONE 7:e43349. doi: 10.1371/journal.pone.0043349

Rasala, B. A., and Mayfield, S. P. (2011). The microalga Chlamydomonas reinhardtii as a platform for the production of human protein therapeutics. Bioengineered 2, 50-54. doi: 10.4161/bbug.2.1.13423

Rasala, B. A., and Mayfield, S. P. (2014). Photosynthetic biomanufacturing in green algae; production of recombinant proteins for industrial, nutritional, and medical uses. Photosyn. Res. doi: 10.1007/s11120-014-9994-7. [Epub ahead of print].

Rasala, B. A., Muto, M., Lee, P. A., Jager, M., Cardoso, R. M. F., Behnke, C. A., et al. (2010). Production of therapeutic proteins in algae, analysis of expression of seven human proteins in the chloroplast of Chlamydomonas reinhardtii: production of therapeutic proteins in algae. Plant Biotechnol. J. 8, 719-733. doi: 10.1111/j.1467-7652.2010.00503.x

Rouwendal, G. J., Wuhrer, M., Florack, D. E., Koeleman, C. A., Deelder, A. M., Bakker, H., et al. (2007). Efficient introduction of a bisecting GlcNAc residue in tobacco $\mathrm{N}$-glycans by expression of the gene encoding human $\mathrm{N}$ acetylglucosaminyltransferase III. Glycobiology 17, 334-344. doi: 10.1093/gly$\mathrm{cob} / \mathrm{cwl} 078$

Ruecker, O., Zillner, K., Groebner-Ferreira, R., and Heitzer, M. (2008). Gaussialuciferase as a sensitive reporter gene for monitoring promoter activity in the nucleus of the green alga Chlamydomonas reinhardtii. Mol. Genet. Genomics 280, 153-162. doi: 10.1007/s00438-008-0352-3

Sasso, S., Pohnert, G., Lohr, M., Mittag, M., and Hertweck, C. (2012). Microalgae in the postgenomic era: a blooming reservoir for new natural products. FEMS Microbiol. Rev. 36, 761-785. x doi: 10.1111/j.1574-6976.2011.00304.x

Schähs, M., Strasser, R., Stadlmann, J., Kunert, R., Rademacher, T., and Steinkellner, H. (2007). Production of a monoclonal antibody in plants with a humanized N-glycosylation pattern. Plant Biotechnol. J. 5, 657-663. doi: 10.1111/j.14677652.2007.00273.x

Schillberg, S., Raven, N., Fischer, R., Twyman, R., and Schiermeyer, A. (2013). Molecular farming of pharmaceutical proteins using plant suspension cell and tissue cultures. Curr. Pharm. Des. 19, 5531-5542. doi: $10.2174 / 1381612811319310008$

Schroda, M., Blöcker, D., and Beck, C. F. (2000). The HSP70A promoter as a tool for the improved expression of transgenes in Chlamydomonas. Plant J. 21, 121-131. doi: 10.1046/j.1365-313x.2000.00652.x

Séveno, M., Bardor, M., Paccalet, T., Gomord, V., Lerouge, P., and Faye, L. (2004). Glycoprotein sialylation in plants? Nat. Biotechnol. 22, 1351-1352. doi: 10.1038/nbt1104-1351 doi: 10.1038/nbt1104-1351

Shaaltiel, Y., Bartfeld, D., Hashmueli, S., Baum, G., Brill-Almon, E., Galili, G., et al. (2007). Production of glucocerebrosidase with terminal mannose glycans for enzyme replacement therapy of Gaucher's disease using a plant cell system. Plant Biotechnol. J. 5, 579-590. doi: 10.1111/j.1467-7652.2007.00263.x

Shaver, S., Casas-Mollano, J. A., Cerny, R. L., and Cerutti, H. (2010). Origin of the polycomb repressive complex 2 and gene silencing by an $E(z)$ homolog in the unicellular alga Chlamydomonas. Epigenetics 5, 301-312. doi: 10.4161/epi.5.4.11608

Specht, E., Miyake-Stoner, S., and Mayfield, S. (2010). Micro-algae come of age as a platform for recombinant protein production. Biotechnol. Lett. 32, 1373-1383. doi: $10.1007 /$ s10529-010-0326-5 
Spolaore, P., Joannis-Cassan, C., Duran, E., and Isambert, A. (2006). Commercial applications of microalgae. J. Biosci. Bioeng. 101, 87-96. doi: 10.1263/jbb.101.87

Staudacher, E. (2012). Methylation-an uncommon modification of glycans. Biol. Chem. 393, 675-685. doi: 10.1515/hsz-2012-0132

Stoger, E., Ma, J. K.-C., Fischer, R., and Christou, P. (2005). Sowing the seeds of success: pharmaceutical proteins from plants. Curr. Opin. Biotechnol. 16, 167-173. doi: 10.1016/j.copbio.2005.01.005

Stork, S., Moog, D., Przyborski, J. M., Wilhelmi, I., Zauner, S., and Maier, U. G. (2012). Distribution of the SELMA translocon in secondary plastids of red algal origin and predicted uncoupling of ubiquitin-dependent translocation from degradation. Eukaryotic Cell 11, 1472-1481. doi: 10.1128/EC.00183-12

Strasser, R., Mucha, J., Mach, L., Altmann, F., Wilson, I. B., Glössl, J., et al. (2000). Molecular cloning and functional expression of beta1, 2-xylosyltransferase cDNA from Arabidopsis thaliana. FEBS Lett. 472, 105-108. doi: 10.1016/S00145793(00)01443-5

Strasser, R., Stadlmann, J., Schähs, M., Stiegler, G., Quendler, H., Mach, L., et al. (2008). Generation of glyco-engineered Nicotiana benthamiana for the production of monoclonal antibodies with a homogeneous humanlike N-glycan structure. Plant Biotechnol. J. 6, 392-402. doi: 10.1111/j.14677652.2008.00330.x

Surzycki, R., Greenham, K., Kitayama, K., Dibal, F., Wagner, R., Rochaix, J.-D., et al. (2009). Factors effecting expression of vaccines in microalgae. Biologicals 37, 133-138. doi: 10.1016/j.biologicals.2009.02.005

Tran, M., Van, C., Barrera, D. J., Pettersson, P. L., Peinado, C. D., Bui, J., et al. (2012). Production of unique immunotoxin cancer therapeutics in algal chloroplasts. Proc. Natl. Acad. Sci. U.S.A. 110, E15-E22. doi: 10.1073/pnas.1214638110

Tran, M., Zhou, B., Pettersson, P. L., Gonzalez, M. J., and Mayfield, S. P. (2009). Synthesis and assembly of a full-length human monoclonal antibody in algal chloroplasts. Biotechnol. Bioeng. 104, 663-673. doi: 10.1002/bit.22446

Twyman, R., Schillberg, S., and Fischer, R. (2013). Optimizing the yield of recombinant pharmaceutical proteins in plants. Curr. Pharm. Des. 19, 5486-5494. doi: 10.2174/1381612811319310004

Van Beers, M. M. C., and Bardor, M. (2012). Minimizing immunogenicity of biopharmaceuticals by controlling critical quality attributes of proteins. Biotechnol. J. 7, 1473-1484. doi: 10.1002/biot.201200065

Van Patten, S. M., Hughes, H., Huff, M. R., Piepenhagen, P. A., Waire, J., Qiu, H., et al. (2007). Effect of mannose chain length on targeting of glucocerebrosidase for enzyme replacement therapy of Gaucher disease. Glycobiology 17, 467-478. doi: $10.1093 /$ glycob/cwm008

Varki, A. (1993). Biological roles of oligosaccharides: all of the theories are correct. Glycobiology 3, 97-130. doi: 10.1093/glycob/3.2.97

Varki, A. (2011). Evolutionary forces shaping the Golgi glycosylation machinery: why cell surface glycans are universal to living cells. Cold Spring Harb. Perspect. Biol. 3:a005462. doi: 10.1101/cshperspect.a005462

Varki, A., Cummings, R. D., Esko, J. D., Freeze, H. H., Stanley, P., Marth, J. D., et al. (2009). Symbol nomenclature for glycan representation. Proteomics 9, 5398-5399. doi: 10.1002/pmic.200900708

Vézina, L.-P., Faye, L., Lerouge, P., D’Aoust, M.-A., Marquet-Blouin, E., Burel, C., et al. (2009). Transient co-expression for fast and high-yield production of antibodies with human-like N-glycans in plants. Plant Biotechnol. J. 7, 442-455. doi: 10.1111/j.1467-7652.2009.00414.x

Vieler, A., Wu, G., Tsai, C.-H., Bullard, B., Cornish, A. J., Harvey, C., et al. (2012). Genome, functional gene annotation, and nuclear transformation of the heterokont oleaginous alga nannochloropsis oceanica CCMP1779. PLoS Genet. 8:e1003064. doi: 10.1371/journal.pgen.1003064

Vitale, A., and Chrispeels, M. J. (1984). Transient N-acetylglucosamine in the biosynthesis of phytohemagglutinin: attachment in the Golgi apparatus and removal in protein bodies. J. Cell Biol. 99, 133-140. doi: 10.1083/jcb.99.1.133
Walsh, G. (2010). Biopharmaceutical benchmarks 2010. Nat. Biotechnol. 28, 917-924. doi: 10.1038/nbt0910-917

Weerapana, E., and Imperiali, B. (2006). Asparagine-linked protein glycosylation: from eukaryotic to prokaryotic systems. Glycobiology 16, 91R-101R. doi: 10.1093/glycob/cwj099

Weinreb, N. J. (2008). Imiglucerase and its Use for the Treatment of Gaucher's Disease. Available online at: http://informahealthcare.com/doi/abs/10.1517/14656566.9. 11.1987 [Accessed December 1, 2013].

Wilson, I. B. H., Zeleny, R., Kolarich, D., Staudacher, E., Stroop, C. J. M., Kamerling, J. P., et al. (2001). Analysis of Asn-linked glycans from vegetable foodstuffs: widespread occurrence of Lewis a, core $\alpha 1,3$-linked fucose and xylose substitutions. Glycobiology 11, 261-274. doi: 10.1093/glycob/11.4.261

Wong, C.-H. (2005). Protein glycosylation: new challenges and opportunities. J. Org. Chem. 70, 4219-4225. doi: 10.1021/jo050278f

Worden, A. Z., Lee, J.-H., Mock, T., Rouze, P., Simmons, M. P., Aerts, A. L., et al. (2009). Green evolution and dynamic adaptations revealed by genomes of the marine picoeukaryotes micromonas. Science 324, 268-272. doi: 10.1126/science. 1167222

Xu, J., Dolan, M. C., Medrano, G., Cramer, C. L., and Weathers, P. J. (2012). Green factory: plants as bioproduction platforms for recombinant proteins. Biotechnol. Adv. 30, 1171-1184. doi: 10.1016/j.biotechadv.2011. 08.020

Zaslavskaia, L. A., Lippmeier, J. C., Kroth, P. G., Grossman, A. R., and Apt, K. E. (2000). Transformation of the diatom Phaeodactylum tricornutum (Bacillariophyceae) with a variety of selectable marker and reporter genes. J. Phycol. 36, 379-386. doi: 10.1046/j.1529-8817.2000.99164.x

Zeleny, R., Kolarich, D., Strasser, R., and Altmann, F. (2006). Sialic acid concentrations in plants are in the range of inadvertent contamination. Planta 224, 222-227. doi: 10.1007/s00425-005-0206-8

Zhao, T., Wang, W., Bai, X., and Qi, Y. (2009). Gene silencing by artificial microRNAs in Chlamydomonas. Plant J. 58, 157-164. doi: 10.1111/j.1365313X.2008.03758.x

Zhu, S., Hanneman, A., Reinhold, V. N., Spence, A. M., and Schachter, H. (2004). Caenorhabditis elegans triple null mutant lacking UDP-N-acetylD-glucosamine: $\alpha-3-\mathrm{D}$-mannoside $\quad \beta 1,2-\mathrm{N}$-acetylglucosaminyltransferase I. Biochem. J. 382, 995-1001. doi: 10.1042/BJ20040793

Zielinska, D. F., Gnad, F., Wiśniewski, J. R., and Mann, M. (2010). Precision mapping of an in vivo $\mathrm{N}$-glycoproteome reveals rigid topological and sequence constraints. Cell 141, 897-907. doi: 10.1016/j.cell.2010.04.012

Conflict of Interest Statement: The authors declare that the research was conducted in the absence of any commercial or financial relationships that could be construed as a potential conflict of interest.

Received: 26 May 2014; accepted: 04 July 2014; published online: 28 July 2014. Citation: Mathieu-Rivet E, Kiefer-Meyer M-C, Vanier G, Ovide C, Burel C, Lerouge P and Bardor M (2014) Protein N-glycosylation in eukaryotic microalgae and its impact on the production of nuclear expressed biopharmaceuticals. Front. Plant Sci. 5:359. doi: $10.3389 / \mathrm{fpls} .2014 .00359$

This article was submitted to Plant Physiology, a section of the journal Frontiers in Plant Science.

Copyright (C) 2014 Mathieu-Rivet, Kiefer-Meyer, Vanier, Ovide, Burel, Lerouge and Bardor. This is an open-access article distributed under the terms of the Creative Commons Attribution License (CC BY). The use, distribution or reproduction in other forums is permitted, provided the original author(s) or licensor are credited and that the original publication in this journal is cited, in accordance with accepted academic practice. No use, distribution or reproduction is permitted which does not comply with these terms. 